UDK 613.64: $616.717-057$

\title{
EXPERIMENTAL ASSESSMENT OF PHENOL INFLUENCE ON IMMUNOREGULATION EX VIVO
}

\author{
O.V. Dolgikh ${ }^{1,2}$, R.A. Predeina1', D.G. Dianova ${ }^{1}$ \\ 1 FBSI "Federal Scientific Center for Medical and Preventive \\ Health Risk Management Technologies", \\ 82, Monastyrskaya St., Perm, 614045, Russia, \\ 2 FSBEI HPE "Perm State National Research University", \\ 15, Bukireva St., Perm, 614990, Russia
}

\begin{abstract}
The peculiarities of immune disorders in the conditions of experimental phenol exposure have seen determined, which are characterized by changing the quantitative composition of the cellular component of the immune system, inhibition of the apoptotic activity of immune cells and dysregulation of the immune response towards Th2-type prevail, which could lead to the development of autoimmune and oncoproliferating processes.

Key words: experimental studies, phenol, apoptosis, immune regulation.
\end{abstract}

Toxic effect of small-molecule chemicals including phenol may lead to poor immune responsiveness and strain of the balancing act between the immunoregulatory mechanisms $[2,3$, 5, 7-9]. Accumulated changes to the immune compartments under chemical exposure may lead to structural disintegration and immune dysfunction, particularly in children, which may result in various somatic diseases including allergies, autoimmune diseases and proliferative processes $[1-4,6]$. With that in sight, it is very important to study phenol effects on immune regulation experimentally.

The purpose of the research is to verify ex vivo the failures in immune regulation in children under phenol exposure.

Materials and methods. The subject being analyzed includes biomasses (blood) such as cell cultures of mononuclear leukocytes and phagocytes in children. To investigate the direct effects of phenol on immune regulation, we analyzed the expression of cytokine development (IL-1 $\beta$, IL-4, IL-6, IL-8, IL-10, IL-17, TNF- $\alpha$, IFN- $\gamma$ ) ex vivo. For that purpose, we analyzed the level of spontaneous mitogen- (PHA, $4 \mu \mathrm{g} / \mathrm{ml}$; konkavalin A, $4 \mu \mathrm{g} / \mathrm{ml}$; lipopolysaccharide, 2 $\mu \mathrm{g} / \mathrm{ml})$ and phenol-induced cytokine products in supernatant whole peripheral blood using the enzyme immunoassay method, the Vector-Best test systems (Russia) and the microplate reader

(C) Dolgikh O.V., Predeina R.A., Dianova D.G., 2014

Dolgikh Oleg Vladimirovich - MD, Head of Department of Immunobiological Diagnostic Methods, Professor of Academic Department of Human Ecology and Life Safety in Perm State National Research University (e-mail: oleg@fcrisk.ru, tel.: 8 (342) 236-39-30).

Predeina Regina Atlasovna - junior research associate at Department of Immunobiological Diagnostic Methods (e-mail: itkinina-regina@yandex.ru, tel.: 8 (342) 236-39-30).

Dianova Dina Gumerovna - CM, senior research associate of the Laboratory of Cellular Diagnostic Methods (e-mail: dianovadina@rambler.ru, tel.: 8 (342) 236-39-30). 
Elx808IU. The impact of phenol on the phagocytal activity was investigated experimentally by adding phenol $\left(0,05 \mathrm{mg} / \mathrm{dm}^{3}\right)$ into blood before incubation with formalinized sheep erythrocytes. The phenol exposure level was selected by testing (we studied the effect of 3 phenol concentrations 0,$01 ; 0,05$ and $0,1 \mathrm{mg} / \mathrm{dm}^{3}$ ) on cells), assessing visual changes in the membranes of immunocytes, and evaluating the phagocytic activity of neutrocytes.

The test results were statistically analyzed with mathematical methods of statistics using Microsoft ${ }^{\circledR}$ Office Excel 2003 and Statistica 6.0 (StatSoft, USA). The accuracy of the obtained results was assessed with the help of the Student test (comparison of groups by quantitative characteristics). The differences in the obtained results were statistically significant at $p \leq 0,05$. To measure the extent to which the two variables are related, we used the Spearman correlation coefficient. The results are presented as a median value $(\mathrm{M})$ and the standard error $(\mathrm{m})$ of the analyzed indicators.

Results and the discussion. We conducted an analysis of the modulation effect of phenol on the immune system experimentally. The assessment of spontaneous cytokine products using peripheral blood of the children under study which characterize the current immune activation showed a statistically significant $(p<0,05)$ increase in the levels of IL-1 $\beta$, IL-6, IL-8 - by 3,4; 4,1 and 5,8 times respectively in children from the main group as compared to the similar indicators in the comparison group (Table 1).

The results indicate that children living in the conditions of exogenous phenol effects had a suppression of the immune response to the slowdown in the apoptotic activity of lymphocytes (a decrease of TNF- $\alpha$ ) and the imbalance of the cytokine producing activity of the immune cells, characterized by the intensification of regulation of the immune response by leukocyte primitive germs (IL-1 $\beta$, IL-8) and inhibition of Th1-mediated immunity (decreased IFN- $\gamma$ ).

Table 1

Comparative indicators of cytokine production by mononuclear cells in children, pg / ml

\begin{tabular}{|c|l|c|c|c|}
\hline \multicolumn{2}{|c|}{ Dytokine production indicators } & $\begin{array}{c}\text { Main group } \\
(n=85)\end{array}$ & $\begin{array}{c}\text { Comparison group } \\
(n=30)\end{array}$ & $\begin{array}{c}\text { Difference between groups } \\
(p)\end{array}$ \\
\hline \multirow{3}{*}{ IL-1 $\beta$} & Spontaneous & $13,45 \pm 2,90$ & $4,00 \pm 1,07$ & 0,003 \\
\cline { 2 - 5 } & Mitogen induced & $7560,31 \pm 552,19$ & $4569,83 \pm 414,06$ & 0,000 \\
\cline { 2 - 5 } & Phenol induced & $799,49 \pm 133,29$ & $193,10 \pm 10,95$ & 0,001 \\
\hline \multirow{3}{*}{ IL -4 } & Spontaneous & $0,71 \pm 0,05$ & $1,40 \pm 0,15$ & 0,000 \\
\cline { 2 - 5 } & Mitogen induced & $1,48 \pm 0,11$ & $4,26 \pm 0,35$ & 0,000 \\
\cline { 2 - 5 } & Phenol induced & $0,85 \pm 0,05$ & $3,57 \pm 0,34$ & 0,000 \\
\hline \multirow{3}{*}{ IL -6 } & Spontaneous & $65,30 \pm 9,79$ & $15,79 \pm 5,09$ & 0,022 \\
\cline { 2 - 5 } & Mitogen induced & $29241,73 \pm 1527,21$ & $19556,67 \pm 1359,10$ & 0,000 \\
\cline { 2 - 5 } & Phenol induced & $9373,95 \pm 970,08$ & $1850,69 \pm 307,58$ & 0,000 \\
\hline \multirow{3}{*}{ IL -8 } & Spontaneous & $1900,62 \pm 294,56$ & $325,04 \pm 79,83$ & 0,001 \\
\cline { 2 - 5 } & Mitogen induced & $27100,86 \pm 1466,79$ & $19506,67 \pm 1765,85$ & 0,004 \\
\cline { 2 - 5 } IL -10 & Shenol induced & $20296,24 \pm 1921,33$ & $935,02 \pm 203,51$ & 0,000 \\
\hline
\end{tabular}


Experimental model and measurement studies

\begin{tabular}{|c|l|c|c|c|}
\hline & Mitogen induced & $176,69 \pm 24,79$ & $99,81 \pm 8,89$ & 0,028 \\
\cline { 2 - 5 } & Phenol induced & $27,07 \pm 4,85$ & $17,52 \pm 1,88$ & 0,166 \\
\hline \multirow{3}{*}{ IL -17} & Spontaneous & $1,40 \pm 0,13$ & $3,97 \pm 0,15$ & 0,000 \\
\cline { 2 - 5 } & Mitogen induced & $16,33 \pm 3,80$ & $28,16 \pm 3,55$ & 0,486 \\
\cline { 2 - 5 } & Phenol induced & $1,94 \pm 0,49$ & $5,09 \pm 0,24$ & 0,062 \\
\hline \multirow{3}{*}{ TNF- $\alpha$} & Spontaneous & $5,00 \pm 0,91$ & $9,51 \pm 0,96$ & 0,001 \\
\cline { 2 - 5 } & Mitogen induced $-\gamma$ & $1991,40 \pm 175,66$ & $3036,67 \pm 270,53$ & 0,002 \\
\cline { 2 - 5 } & Phenol induced & $111,15 \pm 21,28$ & $105,39 \pm 8,88$ & 0,877 \\
\cline { 2 - 5 } & Mitogen induced & $2,18 \pm 0,49$ & $5,60 \pm 0,85$ & 0,001 \\
\cline { 2 - 5 } & Phenol induced & $647,61 \pm 108,14$ & $300,17 \pm 40,15$ & 0,023 \\
\hline
\end{tabular}

Table 2

Indicators phagocytic immunity in children under the experimental conditions ex vivo

\begin{tabular}{|c|c|c|c|c|c|c|c|c|}
\hline \multirow[b]{2}{*}{ Indicator } & \multicolumn{2}{|c|}{ Spontaneous level } & \multirow[b]{2}{*}{$p_{1}$} & \multicolumn{2}{|c|}{ Phenol induced Level } & \multirow[b]{2}{*}{$p_{2}$} & \multirow[b]{2}{*}{$p_{3}$} & \multirow[b]{2}{*}{$p_{4}$} \\
\hline & $\begin{array}{l}\text { Main } \\
\text { group } \\
(n=17) \\
M \pm m\end{array}$ & \begin{tabular}{|c|} 
Compariso \\
n group \\
$(n=15)$ \\
$M \pm m$
\end{tabular} & & $\begin{array}{l}\text { Main group } \\
\quad(n=17) \\
M \pm m\end{array}$ & $\begin{array}{c}\text { Comparison } \\
\text { group } \\
(n=15) \\
M \pm m\end{array}$ & & & \\
\hline Phagocytosis percent & $43,82 \pm 2,2$ & $52,00 \pm 3,1$ & $<0,05$ & $39,00 \pm 2,5$ & $51,47 \pm 3,4$ & $<0,05$ & $<0,05$ & $>0,05$ \\
\hline Phagocytic value, standard unit & $0,71 \pm 0,05$ & $0,92 \pm 0,08$ & $<0,05$ & $0,53 \pm 0,04$ & $0,84 \pm 0,07$ & $<0,05$ & $<0,05$ & $>0,05$ \\
\hline Absolute phagocytosis, $10^{9} / 1$ & $1,300 \pm 0,1$ & $2,850 \pm 0,5$ & $<0,05$ & $1,16 \pm 0,1$ & $2,66 \pm 0,5$ & $<0,05$ & $>0,05$ & $>0,05$ \\
\hline
\end{tabular}

Note:

$p_{1}$ - statistical significance of the inter-group differences $(\mathrm{p}<0,05)$ spontaneous phagocytosis;

$p_{2}$ - statistical significance of the inter-group differences $(p<0,05)$ induced phagocytosis;

$p_{3}$ - statistical significance $(p<0,05)$ of the spontaneous and induced phagocytosis in the main group;

$p_{4}$ - statistical significance $(p<0,05)$ of the spontaneous and induced phagocytosis in the comparison group.

It was determined that the cells of the peripheral blood of children surveyed have a high cytokine producing potential that manifests itself in a statistically significant increase in the production of the studied cytokines in the mitogenic stimulation mode. The reason for this, on the one hand, is the ability of the child's body cells to rapid response, on the other - it reflects the biological significance of these cytokines as activators and regulators of many physiological and pathological processes.

A comparative analysis of mitogen induced production of cytokines found significant $(\mathrm{p}$ $<0,05)$ increase in production of IL-1 $\beta$, IL-6, IL-8, IL-10 and IFN- $\gamma$ in the blood cells of children from the main group by $1.7,1,5,1.4,1.8$ and 2.2 times compared with those in the comparison group (Table 2). Empirically chosen for the experimental conditions, the working phenol concentration equal to $0.05 \mathrm{dm} 3$, was characterized by the absence of visual changes in immune cell membranes and did not cause loss of the ability of neutrophils to phagocytosis.

The study of phenol stimulated cytokine production in peripheral blood mononuclear cells revealed that phenol in the concentration of $0.05 \mathrm{mg} / \mathrm{dm} 3$ had cytokine stimulating influence over both pro- and anti-inflammatory cytokines. With that, phenol has a significant ability to activate the synthesis of cytokines in the interaction with the blood cells of children exposed to the 
exogenous effects of phenols. Thus, the children of the main group showed increased phenolinduced activation of the synthesis of IL-1 $\beta$, IL-6, IL-8, IL-10 and TNF- $\alpha$ - by $1.2 ; 1.2 ; 3.7 ; 1.2$ and 2.0 times, respectively, relative to the same indicators of the comparison group. At the same time, the children of the main group showed no activation of the synthesis of IL-17 and IFN- $\gamma$ under the influence of phenol.

The study of the phagocytic immunity in experimental phenol exposure in children of the main group showed a statistically significant $(\mathrm{p}<0,05)$ decrease in the relative phagocytosis and phagocytic number (Table 2).

The findings suggest that the phagocytic activity of immune cells in children is unhibited under phenol exposure provided its content in the blood is initially greater than the background concentration and the concentration in the comparison group.

Conclusions. It was experimentally proved that phenol has an modulatory effect on cytokine production by mononuclear and phagocytic activity of neutrophils, resulting in reliable stimulation of phenol-induced production of IL-1 $\beta$, IL-6, IL-8, IL-10, TNF- $\alpha$ at $1.2 ; 1.2 ; 3.7 ; 1.2$ and 2.0 times as compared to the comparison group, and suppression of the induced production of IFN by criteria-g and IL-17, and reduction in the relative phagocytosis and phagocytic.

\section{References}

1. Gigienicheskie aspekty narusheniya zdorov'ya detey pri vozdeystvii khimicheskikh faktorov sredy obitaniya [Hygienic aspects of children's health violation from exposure to chemical environmental factors]. Ed. N.V. Zaytseva. Perm': Knizhnyy format, 2011. 489 p.

2. Zaytseva N.V., Dolgikh O.V., Dianova D.G. Modulyatsiya zhiznennogo tsikla kletki v usloviyakh ekspozitsii fenolami [Modulation of cell cycle life under phenol exposure]. Kazanskiy meditsinskiy zhurnal, 2012, vol. XCIII, no. 4, pp. 683-687.

3. Zaytseva N.V., Dolgikh O.V., Dianova D.G. Osobennosti kletochnogo zvena immuniteta $\mathrm{u}$ detey $\mathrm{v}$ usloviyakh vneshnesredovoy ekspozitsii toluolom, formal'degidom, fenolom [Peculiarities of cellular immunity in children in the conditions of environmental exposure to toluene, formaldehyde, phenol]. Izvestiya Samarskogo nauchnogo tsentra Rossiyskoy akademii nauk, 2012, vol. 14, no. 5 (2), pp. 341-343.

4. Avaliani S.L., Andrianova M.M., Pechennikova E.V., Ponomareva O.V. Okruzhayushchaya sreda. Otsenka riska dlya zdorov'ya (mirovoy opyt) [Environment. Health risk assessment (international experience)]. Moscow, 1996. 159 p.

5. Bernard S.M. The potential impacts of climate variability and change on air pollutionrelated health effects in the United States. Environ. Health. Perspect, 2001, vol. 109, suppl. 2, pp. 199-209.

6. Braga M. Environment and T regulatory cells in allergy. Science of The Total Environment, 2012, vol. 423, pp. 193-201.

7. Descotes J. Assessment of immunotoxic effects in humans. Clin. Chem, 1995, vol. 41, no. 12 , pp. $1870-1873$.

8. Descotes J., Vial Th. Immunotoxic effects of xenobiotics in humans: A review of current evidence. Toxicology in Vitro, 1994, vol. 8, no. 5, pp. 963-966. 
9. Duramad P. Cytokines and other immunological biomarkers in children's environmental health studies. Toxicol. Lett, 2007, vol. 172 (1-2), pp. 48-59. 